\title{
BMJ Open Risk factors for bloodborne viral hepatitis in healthcare workers of Pakistan: a population based case-control study
}

\author{
Zulfikar A Gorar, ${ }^{1}$ Zahid A Butt, ${ }^{2}$ Imrana Aziz ${ }^{3}$
}

To cite: Gorar ZA, Butt ZA, Aziz I. Risk factors for bloodborne viral hepatitis in healthcare workers of Pakistan: a population based case-control study. BMJ Open 2014;4:e004767. doi:10.1136/bmjopen-2013004767

- Prepublication history and additional material for this paper is available online. To view these files please visit the journal online (http://dx.doi.org/10.1136/ bmjopen-2013-004767).

Received 4 January 2014 Revised 30 June 2014 Accepted 1 July 2014

CrossMark

\footnotetext{
${ }^{1}$ Health Services Academy, Chak Shahzad, Islamabad, Pakistan

2Department of Public Health, Pakistan Institute of Ophthalmology, Al-Shifa Trust Eye Hospital, Rawalpindi, Pakistan ${ }^{3}$ Department of General Surgery, Dow University of Health Sciences, Karachi, Pakistan
}

Correspondence to Dr Zulfikar Gorar; zulfikar.gorar@hsa.edu.pk

\section{ABSTRACT}

Objectives: A high prevalence of viral hepatitis $B$ and $C$ was found among healthcare workers during a province-wide screening in Sindh Province, Pakistan. A follow-up study was undertaken to identify risk factors for this high prevalence in healthcare workers. Design: Population based case-control design. Setting: Public sector healthcare facilities in a rural district of Pakistan.

Participants: Healthcare workers who were screened for hepatitis B surface antigen ( $\mathrm{HBsAg})$ and hepatitis C virus (HCV) antibodies. 178 healthcare workers employed at the public sector clinics and hospitals of the district were approached, of which 14 refused to participate. Cases had detectable serum antibodies against HCV and the presence of $\mathrm{HBsAg}$. Healthcare workers non-reactive to $\mathrm{HCV}$ antibodies and with no HBsAg were controls. These were matched in a ratio of 1:1.

Outcome measure: Detectable serum HBsAg and HCV antibody titer were taken as outcome. $O R$ for various exposures was calculated; those with $p<0.25$ were entered in a multivariate logistic regression model to find out significant predictors.

Results: Needle stick injury (OR=6; $\mathrm{Cl}_{95} 1.4$ to 23 ), recapping the needle ( $\mathrm{OR}=5.7 ; \mathrm{Cl}_{95} 1.1$ to 28 ), wound care at accident and emergency of a hospital ( $\mathrm{OR}=5.5$; $\mathrm{Cl}_{95} 1$ to 28), female gender (OR=3.4; $\mathrm{Cl}_{95} 1$ to 12 ) and more than 10 years of formal education $\left(\mathrm{OR}=0.25 ; \mathrm{Cl}_{95}\right.$ 0.07 to 0.8 ) were associated with hepatitis $C$. Hepatitis $B$ was found to be associated with trying to bend or break a needle after use (OR=4.9; $\mathrm{Cl}_{95} 1$ to 24).

Conclusions: Healthcare workers in Pakistan are at additional risk of exposure to bloodborne pathogens. Bidimensional risk factors present at individual and broader health systems levels are responsible. Occupational safety, health trainings and redesigning of the curriculum for allied health professionals are required.

\section{INTRODUCTION}

Healthcare workers (HCWs) around the world are at additional risk for acquiring bloodborne pathogens (BBP) like hepatitis B virus (HBV), hepatitis C virus (HCV) and HIV when

\section{Strengths and limitations of this study}

- Research was conducted by interviewing health workers at multiple clinics and hospitals in a district based primary healthcare delivery system; hence, results can be generalised for other similar settings in Sindh, Pakistan.

- This study was a follow-up of province-wide screening; hence, we could not enrol the incident cases of hepatitis B or C.

- The number of participants involved in surgery or dental procedures was small, which could have resulted in non-significant associations for these important risk factors.

- Recall bias cannot be ignored when mentioning different exposures.

compared to any other occupational group. ${ }^{1}$ This is usually due to the unique nature of their occupation which involves working with exposure prone procedures during healthcare delivery. An exposure that might place HCWs at risk for BBP is defined as a percutaneous injury (eg, a needle stick or cut with a sharp object) or contact of the mucous membrane or non-intact skin (eg, exposed skin, ie, chapped, abraded or afflicted with dermatitis) with blood, tissue or other body fluids that are potentially infectious. ${ }^{2}$ The risk of developing serological evidence of hepatitis B is high (32$67 \%$ ) when blood is both hepatitis B surface antigens (HBsAg) and envelop antigen (HBeAg) positive. It reduces $(23-37 \%)$ with HBsAg-positive but HBeAg-negative blood. ${ }^{2}$ The average risk of seroconversion for an HCW after sustaining a sharp injury caused by a hepatitis $\mathrm{C}$ contaminated instrument is reported to be as high as $10 \% .^{3}$

Pakistan has a moderately high prevalence of hepatitis in the general population ${ }^{4}$ (hepatitis C: $4.9 \%$ and hepatitis B: $2.5 \%$ ), but the prevalence of viral hepatitis $\mathrm{C}$ is steadily rising in rural Pakistan. ${ }^{5}$ In 2007 2008, the Ministry of Health Pakistan, under 
its National Programme for Prevention and Control of Hepatitis, undertook the screening of HCWs in the southern province of Sindh; an HCW was defined as any category of employee working in the healthcare delivery at public sector health outlets. Altogether, 11670 HCWs were screened in the whole province; during this exercise, a standard laboratory procedure was adopted whereby blood of the consenting HCW was drawn at the workplace, centrifuged at the spot and brought back to the central pathology laboratory on the same day in cold chain. Temperature was maintained between $2^{\circ} \mathrm{C}-8^{\circ} \mathrm{C}$. Serum was analysed in the third generation ELISA using BIORAD and J\&J USA Kits. Out of the total screened in the province, $851(7.29 \%)$ were $\mathrm{HBsAg}$ reactive and 713 $(6.16 \%)$ were $\mathrm{HCV}$ antibodyreactive. ${ }^{6}$ These figures are high when compared with other reported national or international figures. Other studies from Pakistan have reported HCV prevalence in HCWs from 5.2\% $( \pm 0.63)$ to $5.6 \% ;^{78}$ for hepatitis $\mathrm{B}$, the estimates vary between $3.25 \%( \pm 1.2 \%)$ and $9 \% .{ }^{9} .{ }^{10}$ The high prevalence of hepatitis B and C among Pakistani HCWs can potentially reduce workforce productivity, ${ }^{11}$ compromise patient safety and affect the health system performance at large.

In order to identify risk factors for the high prevalence of hepatitis in Sindh Province as compared to national and international reports, we identified a cohort of HCWs at district Jamshoro of Sindh province having serum antibodies against HCV and the presence of HBsAg. District Jamshoro was selected due to its very high prevalence of HBsAg (24\%) and antibodies against hepatitis C (11.7\%) when compared with other districts.

\section{MATERIALS AND METHODS}

The study was conducted from February 2012 to May 2012 as a follow-up of Government sponsored province wide, generalised screening of HCWs in 2007-2008. To identify work-related risk factors for the high prevalence hepatitis $\mathrm{B}$ and $\mathrm{C}$, we used a prevalent case-control design to establish significant risk factors and make recommendations for health services management. Presence of HBsAg and antibodies against HCV in blood was taken as outcome. Definition and identification: Cases were HCWs with documented evidence of antibodies against $\mathrm{HCV}$ and the presence of HBsAg. ${ }^{12}$ Control subjects were those HCWs who did not have detectable serum antibody titre against hepatitis $\mathrm{C}$ or the presence of HBsAg. Assuming a common workplace poses a similar set of risk factors; for each case, one control from the same clinic or workplace was selected. Further matching was done between various cadres of health workers; for example, a nurse and operation theatre assistant was matched against their own cadre. We identified needle stick injury (NSI) to health workers as an exposure; published evidence reports NSI incidence in Sindh between $45 \%$ and $85 \% .^{13-16}$ These studies have largely been undertaken at tertiary hospitals with a high volume of patients. Health facilities in our area of study were predominantly primary and secondary care hospitals of a district with less patient load. A sample of 77 cases was calculated by assuming an exposure rate of $40 \%$ among controls, a two tailed significance level of $5 \%$ and a power level of $90 \%$ at an OR of 2 . The statistical formula used to determine the number of study participants in each group is as follows ${ }^{\mathrm{i}}$ :

$$
\begin{gathered}
\left(\left\{\mu \sqrt{ }\left(\left[\pi_{1}\left(1-\pi_{1}\right)+\pi 2\left(1-\pi_{2}\right)+\mathrm{v} \sqrt{ } 2 \pi(1-\pi)\right\}\right)^{2} /\right.\right. \\
\left(\pi_{2}-\pi_{1}\right)^{2}
\end{gathered}
$$

To account for potential refusals, we raised the sample size to 90 in the case group and 90 in the control group. Sampling technique: District health authorities maintained a database of 657 screened HCWs, of which 227 were reported as reactive. Reactive subjects were taken as cases and non-reactive cases were taken as controls. Sampling of cases and controls was done by the simple random sampling method from the database. For every case, a control was selected from the same hospital. Cases and controls were approached at the workplace for a detailed interview. Informed consent was taken. Questionnaire: The following information was obtained by interviewing each case and control on a pretested questionnaire (A) involvement in exposure prone procedures at healthcare settings-surgery, working in blood banks, handling infectious waste at a pathology laboratory, major dental procedures; (B) practices of safe injection deliveryusing a separate tray for syringes, use of gloves, recapping the needles, use of sharp containers; (C) miscellaneous risk factors-family member with hepatitis, receiving blood transfusion, vaccination, post-traumatic suturing, education, number of years served. Since past exposure was being measured, recall bias was identified as an important bias and multiple checks in the questionnaire were used along with in-built triangulation. Statistical analysis: Data were entered into SPSS V.20 for analysis. A description of baseline characters of the two groups is provided. Although routes of blood transmission are shared by the two viruses, the risk of transmission for a similar exposure is disproportionally greater for hepatitis B than for hepatitis C, we report the two viruses separately as pooling HCV and HBV infection is not epidemiologically appropriate. A crude estimation of association was obtained by calculating unadjusted OR and $95 \%$ CI. This was done by univariate logistics regression. Exposures with OR having $\mathrm{p} \leq 0.25$ were entered in a binary logistic regression model. The final model was based on statistical significance and biological plausibility.

\section{RESULTS}

A total of 178 participants (89 cases and 89 controls) working at various public sector primary and secondary

${ }^{\mathrm{i}} \pi_{1}=$ Proportion of control exposed, $\pi_{2}=$ Proportion of cases exposed, calculated from $\pi_{2}=\pi_{1} \mathrm{OR} / 1+\pi_{1}(\mathrm{OR}-1), \pi=\pi_{1}+\pi_{2} / 2$ 
Table 1 Baseline characteristics of the respondents

\begin{tabular}{|c|c|c|}
\hline Variables & $\begin{array}{l}\text { Cases=81 } \\
n(\%)\end{array}$ & $\begin{array}{l}\text { Controls=83 } \\
\text { n (\%) }\end{array}$ \\
\hline \multicolumn{3}{|l|}{ Age in years } \\
\hline $15-25$ & 0 & $2(2.4)$ \\
\hline $26-35$ & $16(19.7)$ & $22(26.5)$ \\
\hline $36-45$ & $26(32)$ & $35(42)$ \\
\hline $46-55$ & $37(45.6)$ & $24(29)$ \\
\hline $56-65$ & $2(2.4)$ & 0 \\
\hline \multicolumn{3}{|l|}{ Gender } \\
\hline Male & $53(65.4)$ & $60(72)$ \\
\hline Female & $28(34.5)$ & $23(28)$ \\
\hline \multicolumn{3}{|l|}{ Education } \\
\hline Graduation & $9(11)$ & $13(15.6)$ \\
\hline Intermediate & $2(2.46)$ & $7(8.43)$ \\
\hline Matriculation & $24(29.6)$ & $34(41)$ \\
\hline Primary & 27 (33.3) & $18(21.6)$ \\
\hline Technical education & $3(3.7)$ & $1(1.2)$ \\
\hline No formal education & $16(19.7)$ & $10(12.4)$ \\
\hline \multicolumn{3}{|l|}{ Seropositivity } \\
\hline Hepatitis B positive & $47(58)$ & 0 \\
\hline Hepatitis C positive & $34(42)$ & 0 \\
\hline Hepatitis negative & 0 & $83(100)$ \\
\hline \multicolumn{3}{|l|}{ Exposures } \\
\hline Involved in major surgeries & $7(8.64)$ & $6(7.2)$ \\
\hline $\begin{array}{l}\text { Dental procedure of any } \\
\text { kind }\end{array}$ & $1(1.2)$ & $2(2.4)$ \\
\hline $\begin{array}{l}\text { Handling infectious material } \\
\text { in lab }\end{array}$ & $8(9.8)$ & $4(4.8)$ \\
\hline Internal instrumentation & $3(3.7)$ & 0 \\
\hline Minor skin surgery & $2(2.46)$ & $7(8.4)$ \\
\hline Worked in blood bank & $3(3.7)$ & $4(4.8)$ \\
\hline Injection delivery of any kind & $45(55.5)$ & $51(61.4)$ \\
\hline Vaccinated for hepatitis B & $50(61.7)$ & $59(71)$ \\
\hline Underwent dental extraction & $34(42)$ & $28(31.3)$ \\
\hline Received blood transfusion & $8(9.8)$ & $3(3.6)$ \\
\hline Any family member with $\mathrm{HBV}$ & $3(3.7)$ & $6(7.2)$ \\
\hline Any family member with $\mathrm{HCV}$ & $5(6.1)$ & $2(2.4)$ \\
\hline Needle stick injury & $47(58)$ & $24(28.9)$ \\
\hline Treated at A\&E of hospital & $70(51)$ & 67 (49) \\
\hline
\end{tabular}

A\&E, accidents and emergency; HBV, hepatitis B virus; HCV, hepatitis $C$ virus.

healthcare hospitals spread across Jamshoro district were approached for an interview. The refusal rate was $7.8 \%$ (14). Two-thirds $(68.9 \%)$ of respondents were males, one-third $(35 \%)$ were educated up to the 10 th grade and $16 \%$ had no formal education and were mostly working as janitorial staff. The baseline characteristics are given in table 1 below. In our study, $53.8 \%$ of staff reported having NSI in the past 6 months. The staff category reporting the frequency of events in order from highest to lowest is as follows: operation theatre staff $(85.7 \%)$, vaccinators ${ }^{\mathrm{ii}}$ $(66.7 \%)$, obstetric staff $(57 \%)$, lady health workers ${ }^{\text {ii }}$ $(55.3 \%)$ and doctors $(40 \%)$. In the univariate analysis, we

${ }^{\mathrm{ii}}$ LHWs and vaccinators are the outreach primary health care staff engaged in immunizations. found NSI to be associated with hepatitis. Cases who had reported NSIs were more prone to contracting hepatitis C $\left(\mathrm{OR}=4.39, \mathrm{CI}_{95} 1.5\right.$ to 12.5$)$ as compared to controls. Cases involved in handling of infectious waste in the pathology laboratory were at increased risk of contracting hepatitis $\mathrm{B}\left(\mathrm{OR}=2.7, \mathrm{CI}_{95} 0.9\right.$ to 8.3). HCWs working in surgeries were at 1.7 times increased risk of getting hepatitis $\mathrm{C}\left(\mathrm{CI}_{95} 0.62\right.$ to 5$)$; on the other hand, they were less likely to get hepatitis $\mathrm{B}\left(\mathrm{OR}=0.58, \mathrm{CI}_{95} 0.2\right.$ to 1.8$)$. This is because $80 \%$ of these are vaccinated against hepatitis B. HCWs having knowledge about unsafe injections as modes of spread for hepatitis B and C were 2.4 times more likely to use sharp disposal boxes. Use of sharp disposal boxes was found to be protective against hepatitis B $\left(\mathrm{OR}=0.25, \mathrm{CI}_{95} 0.089\right.$ to 0.699$)$. Those who were ever treated for small wounds at the accidents and emergency (A\&E) department of a public sector hospital were more likely to have hepatitis when compared to controls who were not treated $\left(\mathrm{OR}=2.26, \mathrm{CI}_{95} 1\right.$ to 5.2$)$. Cases were more likely to have another family member suffering from hepatitis as compared to controls $\left(\mathrm{OR}=2.6, \mathrm{CI}_{95} 0.4\right.$ to 14$)$. Blood transfusion was a risk factor $\left(\mathrm{OR}=2.9, \mathrm{CI}_{95}\right.$ 0.75 to 11.9) for contracting disease; the risk of hepatitis $\mathrm{B}$ appears to be slightly higher $\left(\mathrm{OR}=2.1, \mathrm{CI}_{95} 0.61\right.$ to 7.3) when compared to the risk for hepatitis $\mathrm{C}(\mathrm{OR}=1.6$, $\mathrm{CI}_{95} 0.39$ to 6.3 ). Univariate analysis shows protective effects against both infections when formal education is 10 years or more; however, in the multivariate model, education emerges as a significant predictor for hepatitis $\mathrm{C}$ only $\left(\mathrm{OR}=0.25, \mathrm{CI}_{95} 0.07\right.$ to 0.8$)$. Vaccination against hepatitis B was also protective against hepatitis B $\left(\mathrm{OR}=0.229, \mathrm{CI}_{95} 0.1\right.$ to 0.48$)$ (table 2). In the final multivariate model for hepatitis $\mathrm{B}$, bending or breaking of the needle puts an HCW at 4.9 times higher risk $\left(\mathrm{CI}_{95} 1\right.$ to 24) (table 3A). Strong predictors of hepatitis $\mathrm{C}$ in the final multivariate model are NSI, attempt to recap the needle after use, more than 10 years of education, being treated at the A\&E department of a hospital and female gender (table $3 \mathrm{~B}$ ).

\section{DISCUSSION}

Bloodborne viral hepatitis is on the rise in Pakistan, and HCWs are at increased risk of contracting disease. At the individual level, this risk has two dimensions, in the first dimension, HCWs are performing hazardous and unsafe injection delivery practices and in the second they seek care as a patient in a system with lax infection control regulations. At a broader level of health system operations, this is due to quality issues in healthcare delivery. We found (1) NSI, (2) attempts at recapping the needle after use, (3) more than 10 years of formal education, (4) female gender and (5) getting wound care at the A\&E department of a hospital to be significantly associated with bloodborne hepatitis among the HCWs of Jamshoro.

Nearly $80 \%$ of the hepatitis infections in health workers of the WHO-EMRO subregion D are attributed 
Table 2 Univariate logistic regression analysis with unadjusted OR for variables associated with viral hepatitis among healthcare workers of district Jamshoro, Sindh Province, Pakistan

\begin{tabular}{|c|c|c|c|c|c|c|}
\hline \multirow[b]{2}{*}{ Variables| } & \multicolumn{2}{|l|}{ Hepatitis B } & \multicolumn{3}{|c|}{ Hepatitis C } & \multirow[b]{2}{*}{ p Value } \\
\hline & Unadjusted OR & $\mathrm{Cl}_{95}$ & p Value & Unadjusted OR & $\mathrm{Cl}_{95}$ & \\
\hline \multicolumn{7}{|l|}{ Exposure prone procedures } \\
\hline Needle stick injury & 2.0 & 0.93 to 4.6 & 0.07 & 4.39 & 1.65 to 11.6 & 0.003 \\
\hline Handling infectious waste & 2.75 & 0.9 to 8.3 & 0.07 & 0.6 & 0.13 to 2.88 & 0.53 \\
\hline Surgery & 0.58 & 0.18 to 1.8 & 0.36 & 1.7 & 0.62 to 5 & 0.28 \\
\hline \multicolumn{7}{|l|}{ Safe injection practices } \\
\hline Recap needle after use & 1.2 & 0.36 to 4.4 & 0.7 & 3 & 0.92 to 9.9 & 0.06 \\
\hline Move around with uncapped needle & 2.8 & 0.53 to 14.7 & 0.2 & 1.4 & 0.24 to 8.1 & 0.7 \\
\hline Use of sharp disposal container & 0.25 & 0.09 to 0.7 & 0.008 & 0.78 & 0.25 to 2.4 & 0.66 \\
\hline \multicolumn{7}{|l|}{ Factors outside workplace } \\
\hline Hepatitis B vaccination & 0.2 & 0.11 to 0.5 & $<0.000$ & - & - & - \\
\hline More than 10 years of educations & 0.6 & 0.29 to 1.1 & 0.1 & 0.5 & 0.23 to 1.1 & 0.08 \\
\hline Female gender & 0.9 & 0.43 to 1.9 & 0.8 & 1.7 & 0.8 to 3.8 & 0.15 \\
\hline Family member with hepatitis & 0.7 & 0.14 to 3.5 & 0.7 & 3 & 0.65 to 14.5 & 0.15 \\
\hline Treated at A\&E of hospital & 1.2 & 0.56 to 2.7 & 0.6 & 2.26 & 1 to 5.2 & 0.05 \\
\hline Received blood transfusion & 2.1 & 0.61 to 7.3 & 0.23 & 1.6 & 0.39 to 6.3 & 0.5 \\
\hline \multicolumn{7}{|l|}{ Staff category } \\
\hline Lady health worker & 0.6 & 0.28 to 1.5 & 0.3 & 1.9 & 0.87 to 4.5 & 0.1 \\
\hline Operation theatre staff & 0.7 & 0.14 to 3.4 & 0.6 & 2 & 0.47 to 8.44 & 0.3 \\
\hline Sanitary workers & 1.2 & 0.36 to 4.4 & 0.7 & 0.7 & 0.15 to 3.5 & 0.7 \\
\hline Outreach vaccination staff & 1.7 & 0.58 to 5.2 & 0.3 & 1 & 0.25 to 3.5 & 0.9 \\
\hline Labour room staff & 1.9 & 0.41 to 8.9 & 0.4 & 1.5 & 0.29 to 8.4 & 0.6 \\
\hline Doctors & 1.6 & 0.27 to 10.2 & 0.6 & 1 & 0.1 to 8 & 0.9 \\
\hline Ward servants & 1.2 & 0.62 to 2.5 & 0.5 & 1.2 & 0.59 to 2.7 & 0.5 \\
\hline Support staff & 1.4 & 0.45 to 4.5 & 0.5 & 2.3 & 0.7 to 7.4 & 0.1 \\
\hline
\end{tabular}

to sharp injuries. ${ }^{1}$ The frequency of NSI reported in our study is lower than that reported from Egypt $(64 \%)$ by Talaat et $a l^{17}$ Those who have had an NSI in the past 6 months were six times more likely to have serological evidence of antibodies against hepatitis C. Moro et $a l^{18}$ reported a NSI frequency of 13 NSI / worker / 100 years among immunisation clinic staff of Dominican Republic, findings from our study are higher than reported by Moro. Low emphasis on safe injection practices during in-service trainings can be a contributory factor. These trainings are reported to be erratic, unplanned and heavily dependent on donor funding. In order to increase the low vaccination coverage, task shifting is done and additional staff whose primary job is not immunisation are trained. ${ }^{19}$ This additional staff is usually given 7-10 days hands-on training with little or no emphasis on the injection safety and sharp injuries expected to occur while delivering any injection, thus predisposing them to NSI. Non-physician healthcare providers in rural areas have a 1.98 times higher risk of having a sharp injury. ${ }^{20}$ Our results are consistent with these findings by Janjua et al. Recapping of needles is a known risk factor for exposure to blood and body fluids in HCWs. ${ }^{21}$ This practice leads to high NSI incidence

Table 3 Multivariable logistic regression analysis of risk factors associated with transmission of hepatitis among healthcare workers in District Jamshoro, Sindh Province, Pakistan

\begin{tabular}{|c|c|c|c|}
\hline Variable & Adjusted OR & $\mathrm{Cl}_{95}$ & p Value \\
\hline \multicolumn{4}{|l|}{ (A) Hepatitis B } \\
\hline Hepatitis B vaccination* & 0.108 & 0.03 to 0.3 & $<0.000$ \\
\hline Bending or breaking needle by hand & 4.9 & 1 to 24 & 0.04 \\
\hline \multicolumn{4}{|l|}{ (B) Hepatitis C } \\
\hline Needle stick injury & 6 & 1.4 to 23 & 0.012 \\
\hline Recap needle after use & 5.7 & 1.1 to 28 & 0.03 \\
\hline More than 10 years of educations & 0.25 & 0.07 to 0.8 & 0.02 \\
\hline Treated at A\&E of hospital & 5.5 & 1 to 28 & 0.03 \\
\hline Female gender & 3.4 & 1 to 12 & 0.04 \\
\hline
\end{tabular}


and we found HCWs performing hazardous injection practices of (A) bending or breaking the needle and (b) trying to recap the needle to have 4.9 and 5.7 times increased risk of presence of HBsAg and antibodies against hepatitis $\mathrm{C}$ in their blood. The number of years worked in the health services is a known risk factor for hepatitis, ${ }^{22}{ }^{23}$ but we did not find it significant.

Health workers having more than 10 years of formal education are less likely to have hepatitis $\mathrm{C}$ antibodies. Yousufzai has also reported years of education as predictors of sharp injury. ${ }^{24}$ The reasons for this phenomenon are twofold, due to the increased awareness of hazardous procedures and due to educational criteria for recruitment of certain staff categories. Staff with less than 10 years education are usually recruited for the service cadre dealing with exposure prone procedures. No association was found between formal education years and hepatitis B.

Universal hepatitis B vaccination of healthcare staff in Sindh Province was started in 2001 and reinforced in 2006. However, vaccine uptake was $70 \%$; this finding is consistent with other data from Pakistan. ${ }^{25-28}$ In our study, a small subset of (20\%) HCWs who were vaccinated against hepatitis B vaccine also had HBsAg in their blood. Hepatitis B vaccine confers an immunity level $>10 \mathrm{mIU} / \mathrm{mL}$ of anti-HBsAg antibodies for at least 10 years; hence, this inconsistent finding can be due to exposure of this group to HBV prior to vaccination. Our study is not conclusive on this and separate research is needed. However, incomplete vaccination is not altogether a developing country phenomenon; 22\% of all the transplant surgeons in the USA were short of three dose hepatitis $\mathrm{B}$ vaccines. ${ }^{28}$

An HCW who has received wound care or stitches at the A\&E department of a hospital has a 5.5 times higher risk of having antibodies against hepatitis C. This risk is not a consequence of occupation but depicts the general condition of infection control at the hospitals and outpatient departments where patients with minor injuries are being sutured. Karmochkine used a casecontrol design among prevalent cases of hepatitis $\mathrm{C}$ and identified wound care as a non-parenteral risk factor with an OR of 10.1. ${ }^{29}$

The National Hepatitis B and C prevalence survey of Pakistan reported a considerably higher prevalence of hepatitis $\mathrm{C}$ in the female gender from 0 to 39 years of age $^{26}$ when compared with the male gender. In a multivariate model, we also found the female gender to be associated with hepatitis $\mathrm{C}$ among health workers of Jamshoro (OR 3.4, $\mathrm{CI}_{95}=1$ to 12). A majority of female HCWs are lady health workers involved in immunisation and were given inadequate training for injection delivery.

\section{CONCLUSION}

HCWs of Jamshoro district in Sindh Province are at additional risk of contracting hepatitis B and C. Risk factors exist at two levels: at the individual level, determinants like education, gender, injection safety practices and uptake of vaccination are significantly associated. Infection control practices at the outpatient and A\&E departments are also associated at the organisational level. The work environment of an HCW cannot be $100 \%$ risk free, but in times of emerging and re-emerging infections, Pakistan needs a health workforce which is aware about the occupational hazards and can take standard precautionary measures while performing risk prone procedures.

Public sector healthcare employees in Pakistan work in an environment where guidelines and continuous education opportunities on risk prone procedures and infection control are minimal. Two interventions can provide quick gains in reducing the transmission of disease: (1) interventions of ongoing NSI surveillance; organised and structured training on occupational exposure to blood body fluid prevention and (2) universal vaccination of HCWs before induction in service.

Acknowledgements The authors wish to acknowledge Dr Munawar Shah and Dr Amanullah Jhatial for their support during the field work.

Contributors ZAG conceptualised the idea, acquired the data and wrote the initial draft with IA and ZAG. ZAB helped in statistical analysis and reviewed the final draft.

Funding Field work for research was partially funded by the Pakistan Medical Research Council.

Competing interests None.

Patient consent Obtained.

Ethical approval Ethical approval was granted by the Pakistan Medical Research Council, Pakistan.

Provenance and peer review Not commissioned; externally peer reviewed.

Data sharing statement Extra data can be accessed via the Dryad data repository at http://datadryad.org/ with the doi:10.5061/dryad.v6f74.

Open Access This is an Open Access article distributed in accordance with the Creative Commons Attribution Non Commercial (CC BY-NC 3.0) license, which permits others to distribute, remix, adapt, build upon this work noncommercially, and license their derivative works on different terms, provided the original work is properly cited and the use is non-commercial. See: http:// creativecommons.org/licenses/by-nc/3.0/

\section{REFERENCES}

1. Prüss-Üstün A, Rapiti E, Hutin Y. Sharps injuries: global burden of disease from sharps injuries to health-care workers. In: Prüss-Üstün A, Campbell-Lendrum D, Corvalán C, Woodward A eds WHO environmental burden of disease series. Geneva: World Health Organization, 2003. [no.3]: 1-40.

2. Centers for Disease Control and Prevention. Updated U.S. Public Health Service Guidelines for the management of occupational exposures to HBV, HCV, and HIV and recommendations for post exposure prophylaxis. MMWR Morb Mortal Wkly Rep 2001; 50(No. RR-11):1-42.

3. Wallis GC, Kim WY, Chaudhary BY, et al. Perceptions of orthopedic surgeons regarding hepatitis $C$ viral transmission: a questionnaire survey. Ann R Coll Surg Engl 2007;89:276-80.

4. Pakistan Medical Research Council. Prevalence of hepatitis $B$ \& $C$ in Pakistan. Islamabad, 2009.

5. Mujeeb SA, Pearce MS. Temporal trends in hepatitis B \& C in family blood donors from interior Sindh. BMC Infect Dis 2008;8:43.

6. Ministry of Health Government of Pakistan, Prime Minister's Program for Prevention and Control of Hepatitis. End of project report. Islamabad, 2011. 
7. Hamid S, Ismail FW, Jaffery W. Hepatitis and the healthcare worker-a Pakistani perspective. J Coll Physicians Surg Pak 2007;17(Suppl 4):240-5

8. Waheed Y, Shafi T, Safi SZ, et al. Hepatitis C virus in Pakistan: a systematic review of prevalence, genotypes and risk factors. World $J$ Gastroenterol 2009;15(Suppl 45):5647-53.

9. Ali M, Idrees M, Ali L, et al. Hepatitis B virus in Pakistan: a systematic review of prevalence, risk factors, awareness status and genotypes. Virol J 2011;8:102-9.

10. Bosan A, Qureshi H, Bile KM, et al. A review of hepatitis viral infections in Pakistan. J Pak Med Assoc 2010;60(Suppl 12):1045-58.

11. Su J, Brook RA, Kleinman NL, et al. The impact of hepatitis $C$ virus infection on work absence, productivity, and healthcare benefit costs. Hepatology 2010:52:436-42.

12. Centers for Disease Control. A comprehensive immunization strategy to eliminate transmission of hepatitis B virus infection in the United States: recommendations of the Advisory Committee on Immunization Practices. Part I: immunization of infants, children, and adolescents. MMWR Recomm Rep 2005;54(No. RR-16):1-23.

13. Aslam M, Taj T, Ali A, et al. Needle stick injuries among health care workers of public sector tertiary care hospitals of Karachi. J Coll Physicians Surg Pak 2010;20:150-3.

14. Zafar A, Aslam N, Nasir N, et al. Knowledge, attitudes and practices of health care workers regarding needle stick injuries at a tertiary care hospital in Pakistan. J Pak Med Assoc 2008;58:57-607.

15. Khurram M, ljaz K, Bushra HT, et al. Needlestick injuries: a survey of doctors working at Tertiary Care Hospitals of Rawalpindi. J Pak Med Assoc 2011;61(Suppl 1):63-5.

16. Manzoor I, Daud S, Hashmi NR, et al. Needle stick injuries in nurses at a tertiary health care facility. J Ayub Med Coll Abbottabad 2010;22 (Suppl 3):174-8.

17. Talaat M, Kandeel A, El-Shoubary W, et al. Occupational exposure to needle-stick injuries and hepatitis $B$ vaccination coverage among health care workers in Egypt. Am J Infect Control 2003;31(Suppl 8):469-74.

18. Moro PL, Moore A, Balcacer P, et al. Epidemiology of needle sticks and other sharps injuries and injection safety practices in the Dominican Republic. Am J Infect Control 2007;35(Suppl 8):552-9.
19. Masud TI, Kumari VN. The expanded program on immunization in Pakistan, recommendations for improving performance. Washington, DC: World Bank Health Nutrition Population Discussion Paper; April 2012. $41 \mathrm{pg}$.

20. Janjua NZ, Khan MI, Mahmood B. Sharp injuries and their determinants among health care workers at first-level care facilities in Sindh Province, Pakistan. Trop Med Int Health 2010;15(Suppl 10) 1244-51.

21. Shokuhi S, Gachkar L, Alavi-Darazam I, et al. Occupational exposure to blood and body fluids among health care workers in teaching hospitals in Tehran, Iran. Iran Red Crescent Med J 2012;14:402-7.

22. Martins A, Coelho AC, Vieira M, et al. Age and years in practice as factors associated with needle stick and sharps injuries among health care workers in a Portuguese hospital. Accid Anal Prev 2012;47:11-15.

23. Attaullah $\mathrm{S}$, Khan $\mathrm{N}$, et al. Prevalence of HBV and HBV vaccination coverage in health care workers of tertiary hospitals of Peshawar, Pakistan. Virol J 2011;8:275.

24. Yousufzai MT, Nisar N, Kakakhel MF, et al. Injection practices among practitioners in private medical clinics of Pakistan. East Mediterr Health J 2013;19:570-5.

25. Memon MS, Ansari S, Nizamani R, et al. Hepatitis B vaccination status in health care workers of two university hospitals. J Liaquat Uni Med Health Sci 2007;6(Suppl 2):48-51.

26. Hussain S, Patrick NA, Shams R. Hepatitis B and C prevalence and prevention awareness among health care workers in a tertiary care hospital. Int J Pathol 2010;8(Suppl 1):16-21.

27. Memon RA, Sheikh MA, Afsar S, et al. Hepatitis B vaccination status and knowledge, attitude, practices of health care workers (HCWs) regarding hepatitis $\mathrm{B}$ and $\mathrm{C}$ in a tertiary care setting of Karachi. Infect Dis J Pak 2007;16(Suppl 4).

28. Halpern SD, Asch DA, Shaked A, et al. Inadequate hepatitis B vaccination and post-exposure evaluation among transplant surgeons prevalence, correlates, and implications. Ann Surg 2006;244(Suppl 2):305-9.

29. Karmochkine M, Carrat F, Dos Santos O, et al. A case-control study of risk factors for hepatitis $C$ infection in patients with unexplained routes of infection. J Viral Hepat 2006;13:775-82. 